\title{
In Camera Inspections Under the Freedom of Information Act
}

Congress passed the Freedom of Information Act ${ }^{1}$ (FOIA) in 1966 in furtherance of its belief that "an informed electorate is vital to the proper operation of a democracy." 2 The Act's major provision ${ }^{3}$ directs government agencies to release identifiable records in their possession to "any person" who requests them, ${ }^{4}$ subject to the nine exemptions "specifically stated"'s in the statute. ${ }^{\circ}$ If the agency fails to release the records on request, the requester may sue in district court for an injunction against the withholding of the records. In such a proceeding, "the court shall determine the matter de novo and the burden is on the agency to sustain its action."7

Although the FOIA has significantly increased the amount of agency information available to the public, ${ }^{8}$ it has also been severely criticized for the imprecise language and apparent arbitrariness of its standards. ${ }^{9}$ Ambiguities in the provisions, together with bureaucratic resistance to the Act's requirements, ${ }^{10}$ have spawned considerable litigation in the Act's short history of operation. ${ }^{11}$

15 U.S.C. $\$ 552$ (1970).

2 S. REp. No. 818, 89th Cong., 1st Sess. 3 (1965) [hereinafter cited as S. ReP. No. 813].

3 Other provisions require the agency to publish certain information in the Federal Register, 5 U.S.C. \$ 552(a)(I) (1970); and to make available for public inspection its final opinions, statements of policy and interpretation, and staff manuals and instructions, id. $\S 552(\mathrm{a})(2)$.

4 Id. § $552(\mathrm{a})(3)$.

5 Id. \& 552(c).

( $I d . \& 552(\mathrm{~b})(1)-(9)$.

7 Id. \& 552(a)(3).

8 See, e.g., House Comm. on Gov't Operations, Administration of the freedom of INFORMation Act, H.R. REP. No. 92-1419, 92d Cong., 2d Sess. 9 (1972) [hereinafter cited as 1972 HOUSE REPORT].

9 For example, Professor Kenneth Culp Davis, the Act's most influential commentator, described it as a "shabby product." Davis, The Information Act: A Preliminary Analysis, 34 U. CHI. L. Rev. 761, 807 (1967); see Epstein v. Resor, 421 F.2d 980, 932 (9th Cir.), cert. denied, 398 U.S. 965 (1970); Consumers Union v. Veterans Administration, 301 F. Supp. 796, 800 (S.D.N.Y. 1969), appeal dismissed as moot, 436 F.2d 1363 (2d Cir. 1971). Interpretation of the Act is complicated by the fact that the House and Senate committee reports on the Act contradict each other in many particulars, and in some instances contradict the statutory language itself. See Davis, supra, at 762-63, 790.

10 See Giannella, Agency Procedures Implementing the Freedom of Information Act: A Proposal for Uniform Regulations, 23 AD. L. REv. 217, 224 (1971). See generally Engel, Introduction: Information Disclosure Policies and Practices of Federal Administrative Agencies, 68 Nw. U.L. REv. 184 (1973).

11 Eighty-two cases were pending on November 1, 1973. Petitioner's Brief for Certiorari 
In reviewing agency claims of exemption under the Act, courts have resorted to in camera inspection of the requested materials. For many years courts have used in camera proceedings to determine whether allegedly protected information should be introduced into evidence, ${ }^{12}$ and the FOIA was "legislated against the backdrop of [these precedents]."13

The first section of this comment discusses the advantages and disadvantages of the in camera procedure. The factors that the court should weigh in determining whether to engage in an in camera review $^{14}$ are then discussed. The third section applies the criteria developed to the specific exemptions of the Act.

\section{The Benefits and Costs of In Camera Inspection}

Stated in its most appealing form, in camera inspection allows the judge to decide the case on its facts. The basic question in a contested FOIA suit is whether certain words fit certain exemptions. Quite apart from the possibility that the agency has deliberately misdescribed its records, ${ }^{15}$ the ambiguities in some of the exemption provisions create situations in which reasonable persons could differ on the classification.

at 9, Rosen v. Vaughn, 94 S. Ct. 1564 (1974), denying cert. to Vaughn v. Rosen, 484 F.2d 820 (D.C. Cir. 1973).

12 Courts have used such procedures for over ninety years. See Badische Anilin und Soda Fabrik v. Levenstein, 24 Ch. D. 145, rev'd on other grounds, L.R. 29 Ch. D. 366 (C.A.), rev'd, L.R. 12 App. Cas. 710 (1883), discussed in Wigmore, Evidence-Trade Secret - How to Prove It as a Plaintiff, 26 ILc. L. REv. 564 (1932). See also Annot., 62 A.L.R.2d 509 (1958).

13 EPA v. Mink, 410 U.S. 73, 88-89 (1973). The House of Representatives has approved an amendment to the Act confirming that "the court . . . may examine the contents of any agency records in camera to determine whether such records or any part thereof shall be withheld . . . " H.R. 12471, 93d Cong., 2d Sess. § I(d) (1974); see 120 Cong. Rxc. H. 1787-803 (daily ed. March 14, 1974). The Senate has passed a similar measure. See S. 2543, 93d Cong., 2d Sess. § 1(b)(2) (1974); 120 Conc. Rec. S. 9310-43 (daily ed. May 30, 1974).

14 FOIA suits are original proceedings conducted in accordance with the Federal Rules of Civil Procedure. However, the actions are functionally similar to appeals from agency decisions, and in this comment they are often discussed as if in the posture of appellate review.

15 Cf. Williams v. IRS, 345 F. Supp. 591 (D. Del. 1972), aff'd per curiam, 479 F.2d 317 (3d Gir. 1973), cert. denied, 94 S. Ct. 448 (1973); Cowles Communications, Inc. v. Department of Justice, 325 F. Supp. 726 (N.D. Cal. 1971). In each case the court required an in camera inspection solely to determine whether the requested records were, as the agency maintained, an investigatory file. See also Engel, supra note 10, at 205-06; Nader, Freedom From Information: The Act and the Agencies, 5 HARv. Giv. Righrs-Giv. LiB. L. REv. 1, 10-12 (1970). "Misdescription" can, of course, also result from the insertion of nonexempt items into an exempt file to prevent disclosure. See Giannella, supra note 10, at 223-24; Nader, supra, at 9-10. 
Congress intended that the courts should make the final determination of the appropriate classification. ${ }^{16}$ A developing body of case law holds that the process of classification properly includes the isolation and disclosure of nonexempt items present in an otherwise exempt document or file, ${ }^{17}$ and the removal of exempt material, such as trade secrets, from a disclosable document. ${ }^{18}$

The virtue of in camera inspection is that it provides an individualized determination. This benefit, however, has its costs. First, an in camera proceeding does not give the requester an opportunity to present an informed interpretation of the facts, and thus denies him procedural protections normally viewed as necessary. ${ }^{19}$ Second, if the requester fails at the trial level, he faces unusual burdens in contesting the ruling on appeal, for the trial court's ruling, unlike the agency's decision, is given considerable weight by the appeals court, and the requester again has no ability to offer alternative interpretations of fact.

In light of these problems, the applicant might be better off if the

10 See S. REP. No. 813 , supra note 2 , at 8 .

17 See, e.g., Sterling Drug, Inc. v. FTC, 450 F.2d 698 (D.C. Cir. 1971); Bristol-Meyers Co. v. FTC, 424 F.2d 935, 938-39 (D.C. Cir.), cert. denied, 400 U.S. 824 (1970).

18 See, e.g., Grumman Aircraft Engineering Corp. v. Renegotiation Bd., 425 F.2d 578 (D.C. Cir. 1970); Tax Analysts \& Advocates v. IRS, 362 F. Supp. 1298 (1973). The statute specifically authorizes such deletions for agency opinions that are made available for public inspection and copying. 5 U.S.C. $\$ 552(a)(2)(1970)$.

19 Duncan v. Cammell, Laird \& Co., [1942] A.C. 624, 640-41; 1 J. Benthas, Rationale of Judicial Evidence 522-24 (1827); Gellhorn, The Treatment of Confidential Information by the Federal Trade Commission: The Hearing, 116 U. PA. L. Rev. 401, 403-04 (1968). Judge Gerhard Gesell expressed such a view quite forcefully in one FOIA case: "It is entirely foreign to our traditions to place papers in the hands of a judge for his private ex parte inspection, excluding them from the eyes of the litigants. This is a course that should be followed only under the most compelling necessity . . . " Moss v. Laird, Civil No. 12454-71 (D.D.C., Dec. 7, 1971) (unreported), quoted in Hearings on the Administration and Operation of the Freedom of Information Act Before a Subcomm. of the House Comm. on Government Operations, 92d Cong., 2d Sess. 2412 (1972) [hereinafter cited as 1972 Hearings]. Gesell's view, however, has not been followed.

In other litigation contexts there has been limited experimentation with disclosure of secret information to an adverse party's counsel, accompanied by a protective order enjoining him from revealing the evidence to anyone, including his client. See Grand Union, Co., 62 F.T.C. 1491 (1963) (business secrets); Columbia Broadcasting Co., 62 F.T.C. 1518 (1963) (same). However, in FOIA actions, where acquiring the information is the purpose of the suit, the temptation to release it would likely be overwhelming in a number of cases. William A. Dobrovir, who has represented a number of FOIA plaintiffs, suggested at House subcommittee hearings that FOIA actions should be conducted in this ' - way. He argued that lawyers could be trusted just as judges conducting as in camera inspection are trusted. 1972 Hearings, supra, at 1396. Dobrovir himself provided evidence to the contrary some months later, however, when a court admonished him for playing a White House tape recording for friends at a party. The tape had been obtained through discovery in a suit brought by Ralph Nader, with Dobrovir as counsel. N.Y. Times, December 19, 1973, at 27, col. 4 . 
judicial applications of the exemptions did not utilize inspection. Even where a mechanical ruling would be against disclosure, a clear rule that uses known facts may spare the requester the considerable expens $\mathrm{e}^{20}$ of bringing an unwarranted FOIA action. In addition, agencies sometimes make offers of partial disclosure, ${ }^{21}$ and judicial standards that did not involve in camera inspection would permit the applicant to determine better the acceptability of such offers.

Third, decisions based on in camera review of evidence have little precedential value, because the judge is unable to give any detailed explanation of his findings. Ignorance of the dispositive facts in prior cases may impede the parties from settling out of court; or, if they do go to trial, they may have problems relying on, distinguishing, or criticizing the reasoning of earlier decisions. ${ }^{22}$

Finally, substantial reliance on in camera review puts great burdens on the resources of the courts and the agencies. The agencies will have to make their decisions on the type of case-by-case basis that in camera inspection involves, not only in the câse being litigated, but also in the vastly larger number of cases $^{23}$ that never reach the courtroom. If the legal standards are subtle, the agency will be unable to entrust the handling of FOIA requests to low-level personnel. The burden of reading and classifying requested documents will absorb the time, and energy of professionals. ${ }^{24}$ The burden of classification increases considerably when the agency is required to dissect a lengthy file into component parts and decide which subsections should be disclosed. ${ }^{25}$ -Although the government is entitled by law to assess "fair and equitable" costs against the requester, ${ }^{26}$ it is under heavy pressure to minimize

20 See 1972 House REPORT, supra note 8, at 73-74. See also Ditlow v. Volpe, 362 F. Supp. 1321, 1326 (D.D.C. 1973), rev'd on other grounds sub nom., Ditlow v. Brinegair, 34 AD. L.2D 520 (D.C. Cir. 1974), petition for cert. filed, 42 U.S.L.W. 3668 (U.S. May 28, 1974).

21 E.g., Robles v. EPA, 484 F.2d 843, 844 (4th Cir. 1973); Fisher v. Renegotiation Bd., 473 F.2d 109, 113 (D.C. Cir. 1972).

22 Cf. Gellhorn, supra note 19, at 403-04.

23 According to a House subcommittee study of the first four years' experience under the Act, fewer than one out of seven initial refusals of FOIA requests resulted in an administrative appeal, and less than half of those cases reached a district court. Further, these figures do not take account of the fact that the vast majority of formal FOrA requests are granted. 1972 Hearings, supra note 19, at 1338-43.

24 See Koch, The Freedom of Information Act: Suggestions for Making Information Available to the Public, 32 Mo. L. REv. 189, 205 (1972). This responsibility can delay considerably the agency's response to the request, $c f$. Giannella, supra note 10, at 223.

25 Koch, supra note 24, at 208-04.

20 Compare 5 U.S.C. $\$ 552(a)(3)$ (1970), with 31 U.S.C. $\$ 483 a$ (1970). 
its charges, ${ }^{27}$ and it commonly does so. ${ }^{28}$ Thus the public bears the cost when judicial requirements of exactitude unreasonably strain the budgets of the agencies. There must be some limits to the burden that Congress intended to impose on the executive branch. ${ }^{29}$

In camera review can also be extremely burdensome to the courts. Reading hundreds of pages of a document or file to decide whether any of them can be disclosed requires considerable time and effort. The task is made especially difficult by the fact that there is no adversary debate to narrow and sharpen the analysis. ${ }^{30}$ Indeed, the agencies have an incentive to thrust this duty upon the court; they may hope that a busy judge will uncritically accept broad claims of exemption in order to avoid the task of intensive review. ${ }^{31}$

In Vaughn $v$. Rosen, ${ }^{32}$ the court of appeals, in order to alleviate the strain on judicial resources, required the agency not only to furnish the requested records to the district court for in camera inspection, but also to submit a "relatively detailed analysis in manageable segments," indexing each claimed exemption to specific portions of the contested documents. ${ }^{33}$ This requirement may be justified as in accord with the agency's statutory burden of proof. ${ }^{34}$ Nevertheless, Vaughn is a disturbing reminder that someone will have a time-consuming, expensive task when determination of the merits of the request is based on intensive examination of the documents. ${ }^{35}$

27 See, e.g., 1972 House REPORT, supra note 8, at 82 (House Committee); cf. Giannella, supra note 10 , at 270 (recommendation of Administrative Conference of the United States that screening should be pcrformed without charge "[a]s a rule").

281972 Hearings, supra note 19, at 1381-82.

29 Irons v. Schuyler, 465 F.2d 608 (D.C. Cir.), cert. denied, 409 U.S. 1076 (1972) (denying, as indiscriminately broad, plaintiff's request for access to all past manuscript decisions of the Patent Office, with appropriate deletions to be made by the Office). But cf. Wellford v. Hardin, 414 F.2d 21, 24 (4th Cir. 1971). See also note 36 infra.

30 Vaughn v. Rosen, 484 F.2d 820, 825 (D.C. Cir. 1973), cert. denied, 94 S. Ct. 1564 (1974).

31 Id. at 826.

$32 I d$.

33 Id. at 826-27. The court suggested that the district judge could employ a special master to further lighten the burden of examination. It is questionable, however, whether this justification for using a master would constitute the "exceptional condition" required by Rule 53(b) of the Federal Rules of Civil Procedure. See La Buy v. Howes Leather Co., 352 U.S. 249 (1957); 87 Harv. L. Rev. 854, 861 (1974). But cf. Comment, An Adjudicative Role for Federal Magistrates in Civil Cases, 40 U. CHr. L. REv. 584 (1973).

345 U.S.C. \& 552(a)(3) (1970).

35 Other devices that courts have used to reduce the burdens of review include inspecting a sample of the documents requested, Fisher v. Renegotiation Bd., $355 \mathrm{~F}$. Supp. 1171, 1173 (D.D.C. 1973); Wecksler v. Shultz, 324 F. Supp. 1084, 1085 (D.D.C. 1971) (mem.); see EPA v. Mink, 410 U.S. 73, 93 (1973); National Cable Television Ass'n v. FCC, 479 


\section{Towards a Flexible Theory}

Unfortunately, the courts have often ignored the burdens that in camera inspections entail, and have failed adequately to develop functional criteria for determination of when in camera inspection is warranted.

In Environmental Protection Agency v. Mink, ${ }^{36}$ the Supreme Court reviewed a government claim under exemption 5 , which protects "inter-agency or intra-agency memorandums or letters which would not be available by law to a party other than an agency in litigation with the agency." 37 The Court found unduly rigid the lower court's suggestion that in camera inspection should be undertaken as a matter of course $^{38}$ and went on to suggest alternative procedures: the judge could accept "detailed affidavits or oral testimony. . . . A representative document of those sought may be selected for in camera inspection. And, of course, the agency may itself disclose the [nonexempt] portions of the contested documents and attempt to show ... that the excised portions constitute the bare bones of protected matter." 39 The Court showed a readiness to treat different exemptions in different ways and suggested that adequate review does not, in all cases, require in camera inspection. ${ }^{40}$ The Court did not, however, explicate the general policies that should guide courts in determining when to engage in in camera inspection. ${ }^{41}$

This section suggests several factors that should be taken into account in such a calculus. These criteria identify situations in which the flexibility and additional factual foundation of in camera review are most needed. The analysis also attempts to define the circumstances in which the benefits of judicial inspection are lower and, consequently,

F.2d 183, 194 (D.C. Cir. 1973); ordering the agency to release indexes to the requested material, so that plaintiff can narrow his request, Irons v. Gottschalk, 369 F. Supp. 403 (D.D.C. 1974); and dismissing a suit on the grounds that a sweeping request is not for "identifiable records" within the meaning of section 552(a)(3), Irons v. Schuyler, 465 F.2d 608 (D.C. Cir.), cert. denied, 409 U.S. 1076 (1972). The Act does not permit use of the latter tactic, however, except in extreme cases. See Bristol-Meyers Co. v. FTC, 424 F.2d 935, 938 (D.G. Cir.), cert. denied, 400 U.S. 824 (1970). See generally Giannella, supra note 10 , at $231-40$.

36410 U.S. 73 (1973).

375 U.S.C. $\$ 552(\mathrm{~b})(5)(1970)$.

38410 U.S. at 93 .

39 Id.

40 With respect to documents for which the national security exemption, section 552(b)(1), was claimed, the Court stated that in camera inspection would never be appropriate. 410 U.S. at 84 . See text and notes at notes 65-69 infra.

41 The Court's only policy argument on this point pertained exclusively to the agency memoranda exemption. See text and notes at notes 135-38 infra. 
may be outweighed by the inconvenience and uncertainty that accompany in camera proceedings.

\section{A. Existence of a Factual Dispute}

If the parties are essentially in agreement on the legally relevant facts in the case, there is no problem for the court to resolve by direct inspection. ${ }^{42}$ This type of case can appear in at least three situations. First, some of the exemptions contain tests that are straightforward enough for judges to determine from the pleadings whether the exemptions are properly invoked.43 Second, the disclosability of some broad types of records will become established by precedent, and judges will recognize that there can be no serious argument on the issue. ${ }^{44}$ Third, even where neither statutory language nor judicial precedent is clear, there may still be agreement about what the records contain-as, for instance, if the question is whether a certain list of names must be released. ${ }^{45}$

\section{B. Relevance of the Contents to the Issue of Exemption}

If the parties disagree on important issues of fact, the court should consider whether the factual dispute can be clarified by in camera inspection. With some of the Act's exemptions, disclosability may depend on such matters as why the records were written or compiled, ${ }^{46}$ how the agency acquired the information within them, ${ }^{47}$ what the agency does with them, ${ }^{48}$ or how the agency plans to use them in the future. ${ }^{49}$ Frequently, analysis of the requested document will not answer these questions. In these cases, affidavits should provide sufficient basis for decision, or agency personnel may testify on the history or the uses of the disputed records. ${ }^{50}$ Witnesses from outside the government might also be asked to testify if disclosure threatened their interests. ${ }^{.1}$

42 See Vaughn v. Rosen, 484 F.2d 820, 824 (D.C. Cir. 1973), cert. denied, 94 S. Cr. 1564 (1974).

43 See text and notes at notes 62-80 infra.

44 Assuming, of course, that there is no allegation of misdescription. See text and note at note 15 supra.

45 See, e.g., Getman v. NLRB, 450 F.2d 670 (D.C. Cir.), stay denied, 404 U.S. 1204 (1971).

465 U.S.C. $\$ \S 552(\mathrm{~b})(5) \&(\mathrm{~b})(7)(1970)$.

47 Id. § 552(b)(4).

48 Id. \$ 552(b)(2).

49 Id. $\$ 552(\mathrm{~b})(7)$.

50 But see Ash Grove Cement Co. v. FTC, 371 F. Supp. 370 (D.D.C. 1973), an unusual case in which the judge ordered in camera inspection of a set of staff minutes so that he could look for evidence that another set of memoranda was disclosable. Here the staff minutes were treated simply as evidence bearing on pending litigation, although the court had already decided that they were not themselves disclosable under the FOIA.

51 See text and note at note 120 infra. 


\section{The Public's Interest in Disclosure}

When these rather mechanical considerations do not yield a clear solution, courts should ask whether the requester's access to the type of information involved in the case deserves special vindication in light of the purposes of the Act. ${ }^{52}$

One of the goals of the FOIA was to redress the balance of power between individuals and agencies, to minimize arbitrary, discriminatory, or erroneous decisions based on "secret law" (undisclosed agency case law and working interpretations of the laws). ${ }^{53}$ The legislative history of the FOIA demonstrates that public disclosure was also intended to serve a broader political function. Congress was concerned that "[a] democratic society requires an informed, intelligent electorate." 54 Information was viewed as the means for a popular check

52 Courts have been slow to recognize that the public's interest in confining the breadth of the exemptions is not equally strong for all nine provisions. Many opinions have cited dictum from Bristol-Meyers Co. v. FTC, 424 F.2d 935, 938 (D.C. Cir.), cert. denied, 400 U.S. 824 (1970): "The legislative plan creates a liberal disclosure requirement, limited only by specific exemptions which are to be narrowly construed." A number of decisions have followed that rule without analyzing whether a narrow construction of the exemption or exemptions involved in the case at bar would be desirable in terms of the Act's specific purposes. See, e.g., Stretch v. Weinberger, 359 F. Supp. 702 (D.N.J. 1973), aff'd, 34 AD. L.2D 534 (3d Cir. 1974) (material allegedly exempt by another statute); M.A. Schapiro \& Co. v. SEC, 339 F. Supp. 467 (D.D.C. 1972) (five exemptions construed).

The only authority Bristol-Meyers cited for its influential remark was section 552(c) of the Act, which states in part: "This section [of the Act] does not authorize withholding of information or limit the availability of records to the public, except as specifically stated in this section." The House Report does not clarify the meaning of "specifically," since it merely re-uses that word in its discussion of subsection (c). H.R. REP. No. 1497, 89th Cong., 2d Sess. 11 (1966) [hereinafter cited as H.R. REP. No. 1497]. However, the Senate Report uses the word "explicitly" as a synonym. S. REP. No. 813, supra note 2, at 10. Thus it appears likely that Congress intended the words "except as specifically stated" to prevent courts from inventing new exemptions of their own, rather than to restrict the breadth of exemptions 1 through 9. This is the interpretation adopted by the Supreme Court in EPA v. Mink, 410 U.S. 73, 79 (1973) (exemptions are made "exclusive" by subsection (c)). Accord, Wellman Industries, Inc. v. NLRB, $490 \mathrm{~F} .2 \mathrm{~d} 427$ (4th Cir. 1974), petition for cert. filed, 42 U.S.L.W. 3668 (U.S. May 28, 1974).

53 "Requiring the agencies to keep a current index of their orders, opinions, etc., ... will prevent a citizen from losing a controversy with an agency because of some obscure and hidden order or opinion which the agency knows about but which has been unavailable to the citizen simply because he had no way in which to discover it." S. REP. No. 813, supra note 2, at 7. See also Davis, supra note 9, at 772-75, 797, 804. The Act's greatest practical effect has perhaps been in this area. See $i d$. at 804; Koch, supra note 24, at $198-200$.

54 H.R. REP. No. 1497, supra note 52, at 12; see Renegotiation Board v. Bannercraft Clothing Co., 94 S. Ct. 1028, 1037 \& n.17, 1039 (1974); Frankel v. SEC, 460 F.2d 813, 81617 (2d Cir.), cert. denied, 409 U.S. 889 (1972); ATtORNEY GeNERAI's MEMORANDUM ON THE Public Information Section of the Administrative Procedure Act iii (1967) [hereinafter cited as ATt'y Gen. Memo.]; cf. Soucie v. David, 448 F.2d 1067, 1080 (1971). 
on executive hegemony, ${ }^{55}$ and exposing agency operations to an extent sufficient to protect the "right of the individual to be able to find out how his Government is operating." 66 Those who received information required to be disclosed by the Act could counter the executive's power to manipulate the electorate through secrecy; they could marshal public opinion to oppose agency action or, if necessary, present the facts to other branches of the government and appeal for relief. ${ }^{57}$

This broad political goal of the FOIA inheres in its structure. The most striking feature of the Act, perhaps, is that it confers equal rights upon "any person," 88 irrespective of his purposes in seeking information. The Senate report states that the Act "eliminates the test of who shall have the right to different information. For the great majority of different records, the public as a whole has a right to know what its Government is doing." 59

Courts should be especially sensitive to demands for disclosure of matters that concern the agency's actions, plans, and policies as they relate to individuals or the agency's responsibility to the public as a whole. In camera inspection is particularly appropriate where an agency may be withholding disclosable information in order to protect its own authority or reputation. ${ }^{60}$

Conversely, certain exemptions protect information the revelation of which would not offer insights into the workings and policies of the agency. For example, applicants sometimes request information about particular third parties. Denials of such requests are inherently less likely to be tainted by motives of concealing the agency's own errors,

55 The Administrative Procedure Act expressly excludes Congress and the judiciary from the disclosure requirements of the FOIA. 5 U.S.C. $\$ 551(1)(A)-(B)(1970)$.

56 H.R. REP. No. 1497, supra note 52, at 6; see S. RIP. No. 813, supra note 2, at 3. Remarks of individual Congressmen during deliberations on the FOIA confirm that the Act's primary purpose was to expose the workings of the executive branch. Examples are collected in Dobkin, The Release of Government-Owned Technical Data Under the Freedom of Information Law: Between Scylla and Charybdis, 14 VILL. L. REv. 74, 76-78 (1968).

57 Cf. H.R. REP. No. 1497, supra note 52, at 2.

585 U.S.C. \& 552(a)(3) (1970).

59 S. REP. No. 813, supra note 2, at 5; see H. REP. No. 1497, supra note 52, at 1. Virtually every FOIA case has explicitly recognized this principle. But see Getman v. NLRB, 450 F.2d 670 (D.C. Cir.), stay denied, 404 U.S. 1204 (1971). The legislative history relied on in Getman does not support its position. It speaks of "the public's" needs. Yet the reports consistently use the words "the public" to refer to the public at large, in contradistinction to "a person." See, e.g., S. REP. No. 813, supra note 2, at 1-2, amendment 7 .

co The Senate report observes that under the public information statute that preceded the FOIA, "[i]nnumerable times it appears that information is withheld only to cover up embarrassing mistakes or irregularities ... ." S. REP. No. 813, supra note 2, at 3. 
and disclosure of the information is unlikely to provide data germane to the policies of the Act. In the absence of an allegation of misdescription, the courts should therefore give agency claims of exemption in these cases more credence and demand a less unmistakable showing-an affidavit instead of an inspection-before sustaining the agency's claim.

\section{SPECIFIC EXEMPTIONS}

\section{A. The Clear Provisions: Exemptions 9, 8, 1, and 3}

Four of the exemptions appear to embody criteria such that factual issues appropriate for in camera resolution simply do not arise. ${ }^{61}$ The paradigmatic examples are exemption 9, which protects "geological and geophysical information and data, including maps, concerning wells," 62 and exemption 8, for "matters . . contained in or related to examination, operating, or condition reports prepared by, on behalf of, or for the use of an agency responsible for the regulation or supervision of financial institutions." 33 There are no reported cases on exemption 9 and only one on exemption 8 . That case turned on the issue of whether the New York Stock Exchange is a "financial institution" within the meaning of the Act; no fact-finding was necessary to resolve the exemption 8 claim. ${ }^{64}$

The Supreme Court's construction of exemption 1 in EPA v. Mink appears to remove any need for in camera inspection under that exemption, which protects "matters that are ... specifically required by Executive order to be kept secret in the interest of the national defense or foreign policy." eliminate uncertainty in this area by enacting a national security exemption that would turn only on whether an item had been designated as secret by a person having authority to classify documents under the provisions of Executive Order $10501 .{ }^{67}$ This fact may be proven by affidavit or testimony. Mink rejects the suggestion made in earlier

61 Assuming, of course, that there has been no allegation of misdescription.

625 U.S.C. \& 552(b)(9) (1970).

$631 d . \& 552(\mathrm{~b})(8)$.

64 M.A. Schapiro \& Co. v. SEC, 339 F. Supp. 467 (D.D.C. 1972). Finding that the materials before it were not among those "reports" protected by exemption 8, the Schapiro court went on to indicate that the identities of persons named in the documents could be deleted to safeguard their privacy. It is not clear from the opinion whether the court found the authority for such deletions in exemption 8 or in the business secrets exemption, 5 U.S.C. § 552(b)(4) (1970). The latter explanation seems more plausible, since the court believed that no "financial institutions" were involved in the case.

65410 U.S. 73 (1973).

885 U.S.C. \& $552(\mathrm{~b})(1)(1970)$.

of 410 U.S. at 82,84 . After suit was filed in Mink, this order was superseded by Exec. 
cases $^{68}$ that a judge faced with a claim under the national security exemption may review the classification at least to the extent necessary to determine that it is not arbitrary or capricious. ${ }^{69}$

In the same case, Mr. Justice Stewart remarked in his concurring opinion: "Similarly rigid is [exemption 3], which forbids disclosure of materials that are 'specifically exempted from disclosure by statute.' Here ... the only 'matter' to be determined in a district court's de novo inquiry is the factual existence of such a statute ...."70 The narrow inquiry presented in an exemption 3 case thus would not ordinarily require an inspection of the contested records.

The simplest exemption 3 case is one in which a statute categorically identifies documents to be withheld. ${ }^{71}$ Examples of such laws are those that protect individual census reports, ${ }^{72}$ reports filed by tobacco dealers, ${ }^{73}$ and commitment records of drug addicts admitted to hospitals

Order No. 11652, 8 C.F.R. 339 (1974). The Court ruled that the two orders must be treated identically for FOIA purposes. 410 U.S. at 84 n.9.

68 See, e.g., Epstein v. Resor, 421 F.2d 930, 933 (9th Cir.), cert. denied, 398 U.S. 965 (1970).

69 When the government has invoked the privilege for national security materials in cases other than FOIA proceedings, the courts have reviewed the claim more closely. See, e.g., United States v. Rcynolds, 345 U.S. 1, 8-10 (1953) (in Federal Tort Claims Act discovery, court should not uphold claim until satisfied that disclosure would endanger military secrets). By resting on statutory construction, Mink apparently leaves these authorities unimpaired.

Opportunities for obtaining public disclosure of classified documents through administrative channels appear limited. Under the Exccutive Order now in force, a member of the public has a right to require an administrative review of whether a document should remain classified, but only for materials that are at least ten years old. Exec. Order No. 11652, \& 5(C)(i), 3 C.F.R. 339, 345 (1974). The Order does not provide for judicial review of this determination. Early experience with the mandatory declassification procedures has revealed a striking lack of cooperation from the executive branch. See Note, Reform in the Classification and Declassification of National Security Information: Nixon Executive Order 11,652, 59 IowA L. REv. 110, 125 (1973).

Each House of Congress has recently passed a bill that would explicitly permit the courts to use in camera inspection to review defenses under the national security exemption. See note 13 supra. If the Act is amended the executive may nonetheless oppose furnishing classified documents for the court to inspect, on the grounds that it would inevitably create dangerous security risks. The Second Circuit rejected a similar claim by the executive in Halpern v. United States, 258 F.2d 36 (2d Cir. 1958), an action brought under the Invention Secrecy Act, which, in the court's view, authorized the in camera proceeding.

70410 U.S. at 95 n.* (Stewart, concurring). See also Epstein v. Resor, 421 F.2d 930, 933 (9th Cir.), cert. denied, 398 U.S. 965 (1970).

71 See generally Staff of Special Subcomm. on Gov't Informiation, House Comm. on Gov't Operations, 86th Cong., 2d Sess., Federal Statutes on the Availability of INFORMATION 244-75 (1960) [hereinafter cited as FEDERAL StatUTES].

72 13 U.S.C. § 9 (a) (1970).

737 U.S.C. $\& 507$ (1970). 
as voluntary patients. ${ }^{74}$ The only issue in such a case is statutory construction. In Legal Aid Society $v$. Shultz ${ }^{75}$ the government sought to withhold minority hiring program compliance reports by relying on a statute that forbade disclosure of all information "obtained by the [Equal Employment Opportunity] Commission pursuant to its authority under this section ...."76 The court ordered the records released, ruling that the statute did not confer any authority on the EEOC to gather the information plaintiff had requested. The EEOC had apparently acquired the data in some other way and thus could not claim the protection of this statute. ${ }^{77}$

A more difficult and presently unsettled issue is whether a document is "specifically exempted from disclosure by statute" if a law prohibits release except where the agency head has made the information available by regulation or by exercising his discretion. ${ }^{78}$ Professor Davis has suggested that such statutes should be considered "specific" enough to satisfy the exemption because, by comparison with the general disclosure provisions of the FOIA, they are more exact expressions of Congress's wishes concerning the particular kinds of information they describe. ${ }^{79}$ Whether or not Davis's view is correct, the task for the court in this situation is to compare two statutes (the FOIA and another) on their face to decide which takes precedence over the other. Judicial inspection of the records is not necessary. ${ }^{80}$

\section{B. Restrained Use of In Camera Review: Exemptions 7, 6, and 4}

1. The Investigatory Files Exemption. By the terms of the seventh exemption, the FOIA's disclosure requirements do not reach matters that are "investigatory files compiled for law enforcement purposes except to the extent available by law to a party other than an agency." 81

7442 U.S.G. $\$ 260$ (d) (1970).

75349 F. Supp. 771 (N.D. Cal. 1972).

7642 U.S.C. \& $2000 \mathrm{e}-(8)$ (e) (1970).

77349 F. Supp. at 777. See also Nichols v. United States, 460 F.2d 671 (10th Cir.), cert. denied, 409 U.S. 966 (1972).

78 Compare Stretch v. Weinberger, 34 AD. L.2D 534 (3d Gir. 1974) (ordering disclosure), with Evans v. Department of Transp., 446 F.2d 821 (5th Cir. 1971), cert. denied, 405 U.S. 918 (1972); People v. Richardson, 351 F. Supp. 733 (N.D. Cal. 1972) (denying disclosure). See generally FenERAL STATUTEs, supra note 71, at 203-26.

79 Davis, supra note 9 , at 786-87.

80 Perhaps if, pursuant to such a statute, an agency promulgates a regulation that requires disclosure of information, such information does not fall within exemption 3. The practical result of this interpretation would be that a requester could gain relief through FOIA enforcement procedures if agency personnel failed to comply with the agency regulation.

815 U.S.C. $\& 552(\mathrm{~b})(7)(1970)$. The "except" clause prevents the Jencks Act, 18 U.S.C. $\S 3500$ (1970), from being overruled by implication. Williams v. IRS, $345 \mathrm{~F}$. Supp. 591 (D. Del. 1972), aff'd per curiam, 479 F.2d 317 (3d Cir.), cert. denied, 94 S. Ct. 448 (1973). 
A few courts have deemed it necessary to order in camera examination of a file to determine whether the literal language of this exemption is applicable, ${ }^{82}$ but it is a straightforward description that ordinarily should not require that step. ${ }^{83}$

Litigation of this exemption has been complicated, however, by a gloss that some courts have added to the words of the provision. In Bristol-Meyers Co. v. FTC, ${ }^{84}$ a leading case, the court directed that on remand the trial court must determine "whether the prospect of enforcement is concrete enough to bring into operation the exemption ...."85 In that case, the complaint that would have been the foundation of the litigation had been withdrawn two years earlier; the implication of the court's statement is that termination of enforcement efforts removes the file from the exception..$^{86}$ This seems in accord with the committee reports' only specific justification for the exemption -to prevent prejudice to a government court action. ${ }^{87}$

Later decisions, however, have imputed other motives to Congress and have ruled that even when an investigation has been terminated, the entire file may be withheld from disclosure in order to protect investigative techniques, the identity of government informers, and the privacy of those who are investigated. ${ }^{88}$ For example, in Aspin $v$. Department of Defense ${ }^{89}$ a Congressman sued for disclosure of the Army's four-volume report of inquiry on the famous My Lai incident. Without reaching the question of whether disclosure could hurt the government's court case at any time in the future, ${ }^{90}$ the court held that the entire report was exempt as an investigatory file. ${ }^{91}$ The plaintiff in Weisberg $v$. Department of Justice ${ }^{92}$ had requested the FBI's spectrographic analyses of bullets involved in the assassination of President John F. Kennedy. Without having to allege that any particular agency

82 Stern v. Richardson, 367 F. Supp. 1316 (D.D.C. 1973); Cowles Communications, Inc. v. Department of Justice, 325 F. Supp. 726 (N.D. Cal. 1971).

83 See, e.g., Ditlow v. Brinegar, 34 AD. L.2D 520 (D.C. Cir. 1974), petition for cert. filed, 42 U.S.L.W. 3668 (U.S. May 28, 1974); Weisberg v. Department of Justice, 489 F.2d 1195 (D.C. Cir. 1973) (en banc); cf. Holiday Magic, Inc. v. FTC, 32 AD. L.2D 793 (D.D.C. 1973).

84424 F.2d 935 (D.C. Cir.), cert. denied, 400 U.S. 824 (1970).

85 Id. at 939.

86 See also Cooney v. Sun Shipbuilding \& Drydock Co., 288 F. Supp. 708 (E.D. Pa. 1968) (rejecting exemption 7 claim for file complied four and a half years earlier, with no apparent prospect of actual use).

87 S. REP. No. 813 , supra note 2, at 9; see H. REP. No. 1497 , supra note 52 , at 11 (giving no justification).

88 E.g., Aspin v. Department of Defense, 491 F. 2d 24 (D.C. Cir. 1973); Frankel v. SEC, 460 F.2d 813 (2d Cir.), cert. denied, 409 U.S. 889 (1972); Cowles Communications, Inc. v. Department of Justice, 325 F. Supp. 726 (N.D. Cal. 1971).

89491 F.2d 24 (D.C. Cir. 1973).

90 See id. at 28 n.27.

$01 \mathrm{Id}$. at 28.

02489 F.2d 1195 (D.C. Cir. 1973) (en banc). 
interest was at stake, the Department successfully resisted disclosure by showing that the analyses were part of the FBI's investigatory files. This interpretation of the investigatory files exemption clearly requires no in camera inspection.

The rule allowing permanent protection for an investigatory file conflicts, however, with the public's valid interest in knowing the way in which agencies are performing their law enforcement functions. If the agencies are able to close off this phase of their activity from public scrutiny, it will be considerably more difficult for the electorate to prevent abuses of prosecutorial discretion. ${ }^{93}$ Further, the historical fact that certain materials were gathered during an investigation bears no necessary relation to the interests that will be served by disclosure or nondisclosure. ${ }^{94}$

The broad interpretation given in Aspin and Weisberg is not necessary. Other exemptions protect the government's interests in nondisclosure-the internal practices exemption protects secret techniques, ${ }^{95}$ and the identities of informers and persons investigated are protected by the business secrets and personal privacy exemptions. ${ }^{96}$ These exemptions limit the scope of potential disclosure under Bristol-Meyers, but the residuum is potentially valuable information that should be available to the public. The Bristol-Meyers approach best balances the aims of the Act with particular needs for confidentiality ${ }^{97}$

93 Cf. K. Davis, Discretionary Justrce: A Preliminary Inquiry 226 (1969). The potential value of the narrower reading of the exemption in bringing public information into the open is illustrated by a recent district court decision giving a television reporter access to Justice Department information on the counterintelligence program maintained by the FBI against radical organizations in the late 1960s. Stern v. Richardson, $367 \mathrm{~F}$. Supp. 1316 (D.D.C. 1973).

94 In Philadelphia Newspapers, Inc. v. Department of Housing \& Urban Development, 343 F. Supp. 1176 (E.D. Pa. 1972), the court held that since FHA appraisers' names were not themselves exempt from disclosure, the fact that they had been inserted into an investigatory file did not necessarily afford any protection.

95 See text and notes at notes 151-58 infra (exemption 2). A recent order by the Attorney General, 38 Fed. Reg. 19029 (1973), to be codified at 28 C.F.R. § 50.8, provides for the public release of Justice Department investigatory files that are fifteen years old, with allowable deletions of, inter alia, investigative techniques and procedures. The order thus attests to the feasibility of separating out matters of technique and releasing the other portions of a file.

96 See text and notes at notes 98-105 \& 124 infra (exemptions 6 and 4). Exemption 4 operates only in a business context; however, a strong argument could also be made that forced disclosure of an informer's identity is precluded by exemption 6 . The invasion of privacy could be deemed "clearly unwarranted" in light of the informer's privilege that is well established at common law. See, e.g., Roviaro v. United States, 353 U.S. 53 (1957); Annot., 8 A.L.R. Fed. 6. (1971).

o7 The Senate's bill to amend the Act, see note 13 supra, would revise the investigatory files exemption so that it explicitly authorizes a balancing of interests along the line of Bristol-Meyers. See 120 Conc. REc. S. 9329-87 (daily ed. May 30, 1974). 
Courts following Bristol-Meyers will conduct an inquiry into whether the contested file is the basis for an ongoing or probable future enforcement proceeding. This inquiry would not, however, require an inspection of the documents. The court's determination of this issue would presumably be based on circumstantial evidence such as the testimony of agency personnel. Thus even the more individualized approach to exemption 7 does not require in camera inspection.

2. The Privacy Exemption. The sixth exemption is for " $[\mathrm{M}]$ atters that are ... personnel and medical files and similar files the disclosure of which would constitute a clearly unwarranted invasion of personal privacy." 98 The legislative history shows unmistakable concern for the privacy rights of individuals, which the Senate committee termed "equally [as] important" as the "broad philosophy of "freedom of information" " of the Act.99 The privacy exemption protects against the release of files on identified persons which agencies such as the Department of Health, Education, and Welfare, the Selective Service System, and the Bureau of Prisons maintain. ${ }^{100}$ An example of its practical application is the Justice Department's routine practice of denying access to identified files of the Immigration and Naturalization Service. ${ }^{101}$ Many such requests have come from creditors of recent immigrants. Insofar as it consists of refusal to give out information on identified persons, the Department's policy seems entirely in accord with Congress's intent. ${ }^{102}$

The exemption has been one of the most frequently invoked, ${ }^{103}$ but there are a bare handful of reported cases that deal with it. The disparity indicates that perhaps the provision should be grouped with the other exemptions that are unambiguous enough to require minimal judicial surveillance..$^{104}$

A more active judicial role would be necessary if courts took it upon themselves to examine these files in camera and separate out "nonsecret" portions for disclosure. ${ }^{105}$ This is not, however, a desirable

185 U.S.C. $\$ 552(\mathrm{~b})(6)(1970)$.

99 S. REP. No. 813, supra note 2, at 3; see H.R. REP. No. 1497, supra note 52, at 6; ATr'Y GEN. MIEMO., supra note 54, at ii (statement of President Johnson at signing of FOIA).

100 S. REP. No. 813, supra note 2, at 9; H.R. REP. No. 1497, supra note 52, at 11.

1011972 Hearings, supra note 19, at 1176; cf. Cowles Communications, Inc. v. Depart. ment of Justice, 325 F. Supp. 726 (N.D. Cal. 1971) (request for immigrant's file denied on investigatory file exemption grounds; congressional intent to protect privacy inferred from personal privacy exemption, which is incorrectly cited as subsection (b)(5)).

102 H.R. REP. No. 1497, supra note 52, at 11.

1031972 Hearings, supra note 19, at 1342.

104 See text and notes at notes 61-80 supra.

105 This practice is advocated by Professor Davis. See Davis, supra note 9, at 798-99. It should be noted that courts have taken the "clearly unwarranted" restriction in sub. 
course. It ignores the fact, widely recognized in other contexts, ${ }^{100}$ that disclosure of much seemingly innocuous information about an identified person will still injure privacy interests if made readily available to "any person." 107 More fundamentally, this judicial solicitude would tend primarily to benefit those who wish to use personal information for commercial or other private purposes, rather than the public at large for whose interests Congress passed the FOIA. ${ }^{108}$. The exemption should of course not be used to prevent the disclosure of information with the identification of the parties removed. The process of rendering a report anonymous, however, will not necessarily require court participation.

3. The Business Secrets Exemption. The fourth exemption, for "trade secrets and commercial or financial information received from a person and privileged or confidential," has been frequently litigated, largely because its phrasing and its legislative history will support several different interpretations. ${ }^{109}$ The most difficult problem has been to define the phrase "privileged or confidential."110 A number of factors are relevant to this question, and they-affect the propriety of in camera review.

In a recent opinion, National Parks \& Conservation Association v. Morton, ${ }^{111}$ the District of Columbia Circuit attempted to clear the air by announcing that records would be deemed "confidential" for pur-

section (b)(6) quite seriously. See Robles v. EPA, 484 F.2d 843 (4th Cir. 1973); Getman v. NLRB, 450 F.2d 670 (D.C. Cir.), stay denied, 404 U.S. 1204 (1971); Wine Hobby, USA, Inc. v. United States Bureau of Alcohol, Tobacco \& Firearms, 363 F. Supp. 231 (E.D. Pa. 1973). Although this wording may confine the number of files that could fall within the exemption, it does not require dissection of the file. Courts are free to resolve the latter issue on policy grounds.

108 Cf. Note, Privacy and Efficient Government: Proposals for a National Data Center, 82 Harv. L. Rev. 400, 410 (1968).

107 But see Getman v. NLRB, 450 F.2d 670, 677 n.24 (D.C. Cir.), stay denied, 404 U.S. 1204 (1971).

108 Id. at 681 (Mackinnon, J., concurring).

109 See generally Davis, supra note 9, at 787-93. The courts fairly consistently have ruled that the exemption refers only to commercial and financial information, and that the protected information must have been received from a person outside the agency. See Note, The Freedom of Information Act-The Parameters of the Exemptions, 62 GEo. L.J. 177, 186-88 (1973) (collecting authorities) [hereinafter cited as Parameters].

110 Perhaps the best illustration of the judiciary's uncertainty on this point is Ditlow v. Volpe, 362 F. Supp. 1321 (D.D.C. 1973), rev'd on other grounds sub nom., Ditlow v. Brinegar, 34 AD. L.2D 520 (D.C. Cir. 1974), petition for cert. filed, 42 U.S.L.W. 3668 (U.S. May 28,1974 ), where the court stated that the test of confidentiality was whether the supplier of the information would customarily disclose it to the public, but then indicated that there would be nothing improper about agency disclosure that prejudiced the supplier's interests. 362 F. Supp. at 1324 n.4.

11134 AD. L.2D 780 (D.C. Cir. 1974). 
poses of the exemption if their disclosure would be likely "(l) to impair the Government's ability to obtain necessary information in the future; or (2) to cause substantial harm to the competitive position of the person from whom the information was obtained." 112 The first alternative in the Morton test points up agencies' legitimate need to preserve the willingness of businesses to turn over information voluntarily. ${ }^{113}$ The second half recognizes that businessmen may have strong proprietary interests in data about their companies. ${ }^{114}$ This criterion, however, might justifiably have been omitted from the definition of "confidential." Business data fitting this description can properly be brought under the "trade secrets" wording. ${ }^{115}$ Further, such information is prima facie exempt from production in civil discovery, ${ }^{116}$ and thus may fall into the "privileged" category of the statutory exemption.

The Morton tests will allow at least some claims under the business secrets exemption to be resolved without in camera inspection. If the agency is relying on the "information-gathering" rationale, it will argue on the basis of the circumstances under which it received the information; knowledge of the specific contents of the records will not help in the determination whether disclosure would retard collection of other data. ${ }^{117}$ For example, according to FCG regulations, citizens may send

$112 \mathrm{Id}$. at 786.

113 See Sperry \& Hutchinson Co., [1965-1967 Transfer Binder] Trade REg. REP. I 17,505 (FTC), aff'd, 256 F. Supp. 136 (S.D.N.Y. 1966); Gellhorn, The Treatment of Confidential Information by the Federal Trade Commission: Pretrial Practices, 36 U. CHr. L. Rev. 113, 149, 163 n.219 (1968).

Professor Gellhorn suggests that the FTC's concern about the drying up of information sources due to threatened disclosure is excessive, because the real impetus for supplying what the agency wants is the fear of compulsory process. Id. at $163 \&$ n.220. His discussion, however, refers primarily to discovery activity in connection with the development of complaints, where use of subpoena powers would be expected. The argument is less persuasive in situations in which the government routinely collects information but does not have authority to require reporting, see, e.g., 1972 Hearings, supra note 19, at 1619 (Bureau of Labor Statistics economic surveys), or where reliance on compulsory means of collection would be inconvenient, $c f$. J. WIGMORE, EvidENCE $\S 2377$ (3d ed. 1940).

A company that does not trust an agency to keep confidential records secret may acquiesce in an agency's erroneous interpretation of substantive law, rather than contest the ruling and risk the dissemination of its information. "Thus, defending a complaint, even with a valid defense, may be more damaging than signing a consent decree." Graber Mfg. Co. v. Dixon, 223 F. Supp. 1020, 1022 (D.D.C. 1963).

114 See Fisher v. Renegotiation Bd., 355 F. Supp. 1171, 1175 (D.D.C. 1973).

115 R. Milgrim, TRAde SeCrets § 2.09[8] (1974); Gellhorn, Business Secrets in Administrative Agency Adjudication, 22 AD. L. REv. 515, 515-16 (1970). See also Kewanee Oil Co. v. Bicron Corp., 94 S. Ct. 1879, 1883 (1974).

116 Gellhorn, supra note 19 , at 409 . In ordinary court litigation the privilege can be overcome if the adverse party shows that the requested material is relevant to his case. R. MILGRIM, supra note 115 , at § 7.06[1][b]. The FOIA plaintiff, however, has no such needs to show. See text and notes at notes 58-59 supra.

117 Similarly, plaintiffs could introduce circumstantial evidence that refuted the assertion 
inquiries to the Commission with a stipulation that if the agency cannot promise to keep the information in the request confidential, it should return the materials without consideration. ${ }^{118}$ Obviously the FCG needs to promise confidentiality in order to acquire such information. Under Morton, a suit for public disclosure of these records would presumably turn on whether such data collection is "necessary," not on the contents of any individual file.

In some instances, the court may be satisfied of a potential harm to the supplier's competitive position without using in camera inspection. The agency might show, for example, that it received the requested records at a hearing that had been kept private at the supplier's insistence. Agencies are generally reluctant to permit public hearings and will do so only with a showing of good cause. ${ }^{110}$ The fact that a private hearing was granted would not bind the court in the FOIA action because review under the Act is de novo; yet the court could reasonably rely on the fact as highly probative of the supplier's interest in continued secrecy. Another mode of review not requiring direct inspection is participation in the action by the supplier himself, intervening under Rule 24 of the Federal Rules of Civil Procedure or making his views known more informally. ${ }^{120}$

In some cases in which the issue is possible competitive harm, in camera inspection will be appropriate. Where the evidence is unclear, the most efficient way to resolve the issue may be for the judge to examine the allegedly confidential data and use his own judgment. In some ways this procedure is preferable to soliciting the supplier's

of a confidential understanding. For example, they might show that the agency had previously released the information to others, without objection from suppliers having notice. See Robles v. EPA, 484 F.2d 843, 846 (4th Gir. 1973) (exemption 6 case).

1181972 Hearings, supra note 19, at 1799-1801.

119 Gellhorn, supra note 115, at 525. See generally Cohn \& Zuckerman, FCC v. Schreiber: In Camera and the Administrative Agency, 56 GEo. L.J. 451 (1968).

120 See Sterling Drug, Inc. v. FTC, 450 F.2d 698, 709 (D.C. Cir. 1971) (disclosure refused where suppliers sought to prevent release); Fisher v. Renegotiation Board, 355 F. Supp. I171, 1175 (D.D.C. 1973) (same); Consolidated Box Co. v. United States, 24 AD. L.2D (Ct. CI. 1974) (disclosure permitted where supplier had opportunity to intervene but did not do so); cf. M.A. Schapiro \& Co. v. SEC, 339 F. Supp. 467 (D.D.C. 1972) (after an in camera inspection, the court authorized the deletion of names of persons who testified in FOIA action):

A supplier who believes that the agency is not adequately defending his rights may also engage in a collateral proceeding to enjoin the government from complying with an FOIA request. See Charles River Park "A", Inc. v. Department of Housing \& Urban Development, 360 F. Supp. 212 (D.D.C. 1973) (relief granted). But see Gellhorn, supra note 19, at 434 \& $n .178$ (injunction available only in exceptional circumstances). This remedy will be effective only if the supplier has notice of the FOIA request. 
opinions on whether disclosure will injure his interests. First, contacting the supplier is frequently a time-consuming process, ${ }^{121}$ in contravention of the FOIA's emphasis on promptness. ${ }^{122}$ Second, there may be too many suppliers to contact feasibly, for example, if the requested information consists of the results of a questionnaire. ${ }^{123}$

In camera inspection will also be appropriate if descriptions of the records indicate that they are heterogeneous, and inspection is likely to permit the court to separate disclosable portions from the whole or delete identifying details. ${ }^{124}$ If internal agency records incorporate information subject to the business secrets exemption, they may be withheld only if any partial release would injure suppliers. ${ }^{125}$ The fact that such records may reveal agency operations, rather than merely facts about private parties, suggests that close, in camera inspection is warranted.

\section{Activist Review: Exemptions 5 and 2}

1. The Memoranda Exemption. The fifth exemption is for "interagency and intra-agency memorandums or letters which would not be available by law to a party other than an agency in litigation with the agency." 126 It is designed to foster unrestrained airing of policy alternatives within the agency decision making process. Congress accepted the agencies' contention that "it would be impossible to have any frank discussion of legal or policy matters in writing if all such writings were to be subjected to public scrutiny." 127 If advisory memoranda were not exempt, the "threat of cross-examination in a public tribunal" might deter policy-makers from offering tentative suggestions, perhaps of a creative or heretical character. ${ }^{128}$ The courts recognize, however, two exceptions to the general exemption of memoranda: factual material that is separable from the advisory material, and opinions that have

121 See 1972 Hearings, supra note 19, at 1556, 1797.

1225 U.S.C. $\$ 552$ (a)(3) (1970).

123 See S. REP. No. 813, supra note 2, at 9.

124 See National Parks \& Conservation Ass'n v. Morton, 34 AD. L.2D 780, 787 (D.C. Cir. 1974); Grumman Aircraft Engineering Corp. v. Renegotiation Bd., 425 F.2d 578 (D.C. Cir. 1970); Tax Analysts \& Advocates v. IRS, 362 F. Supp. 1298, 1307 (D.D.C. 1978). See also Fisher v. Renegotiation Bd., 473 F.2d 109 (D.C. Cir. 1972).

126 Cf. Fisher v. Renegotiation Bd., 355 F. Supp. 1171, 1175 (D.D.C. 1973).

1265 U.S.C. $\$ 552(\mathrm{~b})(5)(1970)$.

127 S. REP. No. 813, supra note 2, at 9.

128 Ackerly v. Ley, 420 F.2d 1336, 1341 (D.C. Cir. 1969). It has also been suggested that the exemption reinforces the principle that responsibility for a decision reached must lie with the official who makes the final judgment, and not with subordinates. Soucie v. David, 448 F.2d 1067, 1081 (D.C. Cir. 1971) (Wilkey, J., concurring). 
been àdoptèd as legal policy or legal interpretations. In camera inspection is extremely desirable in isolating factual material, but of little utility in discovering when a recommendation is in fact "secret law."

a. Factual Materials. The requirement in exemption 5 that the material must not be "available by law to a [private party] in litigation" has consistently been held to deny exemption to portions of advisory memoranda that do not expose the decision making process. ${ }^{129}$ This reading reflects Congress's attempt to "delimit the exception as narrowly as consistent with efficient Government operation."130

Disclosure of facts that bear on important decisions is at the heart of the FOIA's concern, for it is essential to public debate on the correctness of the decision. In camera inspection is a method of insuring that the maximum amount of disclosable material reaches the public.

In Soucie v. David, ${ }^{\mathbf{1 3 1}}$ citizens filed suit under the Act to acquire a report prepared by the Office of Science and Technology, assessing the government's program to develop the SST aircraft. The government claimed exemption because the report contained "opinions, conclusions, and recommendations prepared for the advice of the President." The District of Columbia Circuit agreed that recommendations are protected by exemption 5 , but remanded the case for a determination whether any nonadvisory, factual portions of the report could be separated out and released. The court said: "It would defeat the purposes of the Act ... to withhold from the public factual information on a federal scientific program whose future is at the center of public debate."132

129 See, e.g., EPA v. Mink, 410 U.S. 73, 89 (1973); Soucie v. David, 448 F.2d 1067 (D.C. Cir. 1971); GSA v. Benson, 415 F.2d 878 (9th Cir. 1969). The qualifying clause is held to refer to the evidentiary rule that government advice memoranda can be withheld. The rule, and thus the exemption, does not reach separable factual matters. See, e.g., Machin v. Zuckert, 316 F.2d 336 (D.C. Cir.), cert. denied, 375 U.S. 896 (1963).

This limitation on "executive privilege" should be distinguished from the decision in the Watergate tapes case, Nixon v. Sirica, 487 F.2d 700 (D.C. Cir. 1973). That case held that, despite a Presidential claim of privilege, records of deliberations and advice within the executive branch were discoverable if the opposing litigant's need to use them as evidence was sufficiently compelling, in the opinion of the court, to outweigh the breach of confidentiality that disclosure would entail. The FOrA exemption should be read, however, to exclude only those items that would be available on a minimal showing of need in litigation. The balancing of need aspects of Nixon $v$. Sirica would therefore not be read into exemption 5. See text and notes at notes 58-59 supra.

130 S. REP. No. 813, supra note 2 , at 9.

131448 F.2d 1067 (D.C. Cir. 1971).

$132 \mathrm{Id}$. at 1090. The rationale for intensive review is no less strong if the subject matter of the requested memoranda does not happen to be the object of contemporary public debate; the FOIA was intended also to bring to light issues that otherwise might be covered up and ignored. 
Court scrutiny of documents for which this exemption is claimed is particularly appropriate because of the risk that the agencies will apply this exemption broadly, ${ }^{133}$ since their own vested interests are likely to be at stake. Disclosure of factual information relevant to policy decisions may expose an agency's inefficiency or administrative errors; it may also give ammunition to those who oppose programs and policies the agency supports, or vice versa. ${ }^{134}$

The Supreme Court suggested in Environmental Protection Agency v. Mink $^{135}$ that courts should be slow to order an in camera inspection to resolve an exemption 5 controversy, because " $[\mathrm{i}] \mathrm{t}$ seems . . . obvious that the very purpose of the privilege, the encouragement of open expression of opinion as to governmental policy is somewhat impaired by a requirement to submit the evidence even [in camera]." ${ }^{136}$ This concern seems excessive. There is no reason for a decisionmaker to be "chilled" by the possibility that a single judge will view his memo-

133 Ackerly v. Ley, 420 F.2d 1936 (D.C. Cir. 1969). A lawyer who frequently represents plaintiffs in FOIA actions has claimed that agency employees do in fact frequently withhold factual portions of policy memoranda, in violation of the Act. 1972 Hearings, supra note 19 , at 1400 .

134 Note, The Freedom of Information Act and the Exemption for Intra-Agency Memoranda, 86 HARv. L. REv. 1047, 1054 n.32 (1973) [hereinafter cited as Intra-Agency].

135410 U.S. 73 (1973).

130 Id. at 93, quoting Kaiser Aluminum \& Chemical Corp. v. United States, 157 F. Supp. 939, 947 (Ct. Cl. 1958). Kaiser Aluminum was decided under the pre-Act doctrine of executive privilege. See note 129 supra. Congress intended to incorporate the privilege into the memoranda exemption, Ackerly v. Ley, 420 F.2d I336, 134 I (D.C. Cir. 1969), and the Fourth Circuit has held that the government enjoys no greater protection under the executive privilege doctrine than it possesses under exemption 5 as construed in Mink. Ethyl Corp. v. EPA, 478 F.2d 47 (4th Cir. 1973).

It has been suggested that a formal claim of executive privilege in an FOIA case requires the court to pay more than ordinary deference to an agency's description of its records. Proponents of this argument maintain that the privilege rests in part on the constitutional doctrine of separation of powers, and thus cannot be eliminated by Congressional action. See Soucie v. David, 448 F.2d 1067, 1081 (D.C. Cir. 1971) (Wilkey, J., concurring). But cf. Davis, supra note 9 , at 793. This position appears to misconceive the nature of the separation of powers principle. In Justice Brandeis's famous formulation, the purpose of the doctrine is "not to promote efficiency but to preclude the exercise of arbitrary power." Myers v. United States, 272 U.S. 52, 293 (1926) (dissent). This standard implies that the constitutional validity of the Act's directive to disclose turns on whether the Act unduly strengthens Congress, not on whether it unduly weakens the executive. Thus Professor Bishop makes his case for executive privilege by pointing to the danger of a Senator Joseph McCarthy badgering helpless agency personnel. Bishop, The Executive's Right of Privacy: An Unresolved Constitutional Question, 66 YALE L.J. 477, 488 (1957).

The FOIA is an exercise of Congressional power, of course, but Congress is not the beneficiary in a direct sense. The principal effect of the Act is to enable the public to uncover and thereby to remedy abuses of executive power. Restrictive application of the memoranda exemption, without additional deference to claims of privilege, does not frustrate, but rather serves, the policies that underlie the separation of powers doctrine. 
randum. What the official could rationally fear is an increased chance that his opinions will be erroneously disclosed to the public. The fact-opinion criterion is not difficult for a court to apply, however, and it is inherently weighted in favor of the agency, because factual material "inextricably intertwined with policymaking processes" is not subject to disclosure. ${ }^{137}$ Thus there is little chance that an in camera search for disclosable chapters or pages in a report will lead to inadvertent release of advisory material, which the memoranda exemption was meant to protect. ${ }^{138}$

The narrow holding of Mink is reasonable: in camera inspection of an intra-agency memorandum should be avoided if the agency can satisfy its burden of proof in other ways. The considerable public interest involved and the distinctive potential for abuse of this exemption suggest, however, that a judge should be particularly cautious before deciding that he is satisfied. with the alternative showing.

b. Secret Law. A second judicial limitation on the scope of exemption $\mathbf{5}$ is the rule that a memorandum adopted by an agency as the basis for its decision in an adjudication must be disclosed, even though recommendatory and therefore exempt under traditional discovery principles. ${ }^{130}$ As the court explained in Sterling Drug, Inc. v. FTC:140 "These are not the ideas and theories which go into the making of the law, they are the law itself, and as such should be made available to the public. Thus, to prevent the development of secret law within the Commission, we must require it to disclose orders and opinions which it actually applies in cases before it." The court remanded the case so that the district judge could examine the contested memoranda and determine whether any of them fit this description.

Although the public interest in curtailing "secret law" is extremely high, ${ }^{141}$ the utility of in camera inspection to further this goal is limited.

137 EPA v. Mink, 410 U.S. 73, 92 (1973); Soucie v. David, 448 F.2d 1067, 1088 (D.C. Cir. 1971).

138 In addition, it can be argued that threatened disclosure of an official's factual conclusions is significantly less "chilling" than the threat that his recommendations and value judgments will be made public, because in the latter situation the potential for embarrassment and personal attack is greater. Note, Intra-Agency, supra note 134, at 1053.

139 The technical justification for this rule is that an agency has an affirmative statutory duty to make such opinions available for public inspection and copying, 5 U.S.C. \$ 552(a) (2)(A)-(B) (1970), and thus they are not "intra-agency." See American Mail Line, Ltd. v. Gulick, 411 F.2d 696, 703 (D.C. Cir. 1969).

140450 F.2d 698, 708 (D.C. Cir. 1971); see American Mail Line, Ltd. v. Gulick, 411 F.2d 696, 703 (D.C. Cir. 1969); Ash Grove Cement Co. v. FTC, 371 F. Supp. 370, 373 (D.D.C. 1973).

141 See text and note at note 53 suppra. 
A court can, of course, examine the decisional documents that were prepared in connection with a given case, hoping that one will identify itself as the one stating the controlling principles of the decision. Yet without prior evidence that such a document exists, ${ }^{142}$ the inquiry is essentially a shot in the dark. In many instances commissioners or high department officials may rely entirely on oral consultation with their subordinates and never express their theories in writing. In other cases, they may consider several recommendations and never fully agree among themselves which governs the decision taken.

A general policy against using in camera proceedings to find memoranda adopted by an agency should, of course, yield to a suitable showing by the plaintiff that such a document probably exists. Proof that the agency customarily explains its decisions in written form would furnish an adequate predicate, or the plaintiff might establish the existence of secret law by referring to evidence contained in a separate document, such as agency staff instructions that refer to a memorandum as if the latter expressed the agency's view on a matter of substantive law. ${ }^{143}$

2. The Internal Practices Exemption. In camera inspection to prevent the growth of secret law is also appropriate in the context of exemption 2, for "matters ... related solely to the internal personnel rules and practices of an agency." 144 The courts are in conflict ${ }^{145}$ over whether the exemption refers only to rules that touch on an agency's physical management of its work force, ${ }^{146}$ as the Senate report maintains, ${ }^{147}$ or extends to virtually all staff instructions, as the House report implies. ${ }^{148}$ Neither of these two readings of the statute is attractive

142 In American Mail Line, Ltd. v. Gulick, 411 F.2d 696 (D.C. Cir. 1969), the Maritime Board rendered a decision against plaintiff in an adjudication, stating that its decision was based on a certain undisclosed memorandum but not openly explaining its reasoning in any detail. The court ordered the release of the memorandum. Such "incorporation by reference," while clearly sufficient to bring section $552(a)(2)(A)$ into play, is unlikely to occur very often.

143 Cf. Ash Grove Cement Co. v. FTC, 371 F. Supp. 370 (D.D.C. 1973).

1445 U.S.C. § 552(b)(2) (1970).

145 See Note, Parameters, supra note 109, at $182-85$ (collecting cases).

146 Benson v. GSA, 289 F. Supp. 590, 594 (W.D. Wash. 1968), aff'd, 415 F.2d 878 (9th Cir. 1969).

147 The Senate Report indicates that subsection (b)(2) protects only matters such as "rules as to personnel's use of parking facilities or regulation of lunch hours, statements of policy as to sick leave, and the like." S. REP. No. 813, supra note 2, at 8 .

148 The House report states that, with a few minor exceptions, "[o]perating rules, guidelines, and manuals of procedure for Government investigators and examiners" are exempt. H.R. REP. No. 1497, supra note 52, at 10. See also ATr'Y GEN. MEMo., supra note 54, at 30-31. 
as a matter of policy. The broad construction of the exemption permits the withholding of much secret law, ${ }^{149}$ but the narrower version may compel the disclosure of the agency's investigative strategy and ultimately undermine the effectiveness of its law enforcement. ${ }^{150}$

The language of the statute suggests a third, more acceptable interpretation-that secret law is disclosable but enforcement strategies are not. ${ }^{151}$ "[I]nformation which either defines or provides a way of determining the extent of substantive rights and liabilities"152 cannot be related "solely" to internal practices of an agency, as exemption 2 would require for protection from disclosure. Agency records of the tactics it employs to monitor compliance with the law, however, do not in themselves prescribe standards for citizen conduct; such records prescribe conduct for government personnel. Enforcement strategy does "relat $[\mathrm{e}]$ solely to the internal ... practices of an agency," because only agency employees have the job of enforcing the law.

This interpretation is supported by the requirements of subsection (a) $(2)(C)$, which provides that agencies must make available for public inspection and copying "administrative staff manuals and instructions to staff that affect a member of the public." The word "administrative" was added late in the drafting of the FOIA, to make the requirement apply to "administrative matters" but not "law enforcement matters." The Senate committee said that this limitation "protects the traditional confidential nature of instructions to Government personnel prosecuting violations of law in court, while permitting a public examination of the basis for administrative action." 153 In Hawkes v. IRS, ${ }^{154}$ the Sixth Circuit endorsed this distinction and termed it the "only legitimate basis" for drawing the line of disclosure for staff instructions. ${ }^{155}$ Exemption 2 should be construed to reinforce that line. ${ }^{156}$

149 See text and note at note 53 supra.

150 "[Plaintiffs seek materials] relating to the general organization, planning and conduct of a 'stakeout.' It takes no peculiar ability in crime detection nor any imagination to conclude that the nature of the instruction that the government gives its law enforcement agents could be of interest to those against whom such techniques are used, and that disclosure of that information would tend to materially lessen the effectiveness of the techniques described and taught." City of Concord v. Ambrose, 333 F. Supp. 958, 959 (N.D. Cal. 1971).

151. Cf. Davis, supra note 9 , at 783 .

152 Cuneo v. Schlesinger, 484 F.2d 1086, 1091 n.13 (D.C. Cir. 1973).

153 S. REP. No. 813, supra note 2 , at 2.

154467 F.2d 787 (6th Cir. 1972).

155 Id. at 794 .

156 In Hawkes the court erroneously assumed that adherence to the Senate's narrow explanation of exemption 2, see note 147 supra, would support subsection (a)(2)(C)'s policy of disclosing administrative, but not law enforcement, instructions. $467 \mathrm{F.2d}$ at 796-97. It failed to realize that law enforcement manuals, even if not available under subsec- 
This interpretation of exemption 2 was in effect adopted without explanation in Cuneo $v$. Schlesinger. ${ }^{157}$ The District of Columbia Circuit ruled that the Department of Defense could refuse to disclose its manual for the auditing of defense contract compliance insofar as it consisted of tactics to be employed in conducting an audit, but that the applicant had a right to know "secret law," such as the accounting principles the government expects contractors to follow. The court remanded, directing the district court to conduct a Vaughn-type in camera inspection and to rule separately on discrete units of the manual..$^{158}$

The detailed examination ordered in Cuneo should be adopted in other exemption 2 cases. The public interest in seeing parts, though not the entirety, of agency staff instructions is strong and is closely related to the goals of the Act. In contrast to the need for circumstantial evidence in the search for secret law under the fifth exemption, a court should be able to discern the import of different sections of a manual from looking at the document itself, at least if a clarifying pleading accompanies it. The relevant test is not difficult to apply, and in camera inspection can provide a better adjudication of the FOIA claim than would be available without it.

\section{GONCLUSION}

In camera inspections enable courts to reach informed results in certain Freedom of Information Act suits. In camera inspections, however, can also cause procedural handicaps to plaintiffs and inconvenience to the agencies and courts. In camera inspections are most valuable when the adverse parties in the suit disagree on the factual nature of the requested records; the application of the claimed exemption depends on the specific contents of the records; or the withholding may conceal information about agency operations. By concentrating their most intensive review techniques on cases that are most likely to present those circumstances-particularly suits involving the memoranda and internal practices exemptions-courts can enforce the FOIA efficiently without sacrificing the ideals of open government that the Act was intended to foster.

Ronald M. Levin

tion (a)(2)(C), are nevertheless available to "any person" under subsection (a)(3) unless protected by one of the nine exemptions. Thus, only the construction suggested in the text supports the outcome favored in Hawkes.

157484 F.2d 1086 (D.C. Cir. 1973).

$158 \mathrm{Id}$. at $1090-91$. 